\title{
Milk Composition and Volume in Meadow Voles and Prairie Voles
}

\author{
Betty McGUIRE ${ }^{1}$, Henry HELLER \& Melinda NOVAK
}

\begin{abstract}
McGuire B., Heller H. \& Novak M., 1988: Milk composition and volume in meadow voles and prairie voles. Acta theriol., 33, 39: 537-544. [With 1 Table]

Meadow and prairie voles differ in frequency and duration of nursing. We examine differences in pattern of maternal investment by comparing the volume and composition of milk produced by the two species. Milk samples were collected on days 4,8 and 12 of lactation, and analyzed for protein, fat and lactose. The milk of meadow and prairie voles differed little in basic composition. The mean volume of milk collected from meadow voles was three times that obtained from prairie voles. This difference cannot be explained solely on the basis of species differences in maternal body size. We suggest that species differences in pattern of milk secretion (i.e., volume of milk secreted per unit time) accompany established differences in nursing behavior.
\end{abstract}

[Dept. of Psychology, University of Massachusetts, Amherst, Massachusetts, 01003, USA]

\section{INTRODUCTION}

Meadow voles (Microtus pennsylvanicus Ord, 1815) and prairie voles (M. ochrogaster Wagner, 1842) differ dramatically in pattern of maternal care (McGuire \& Novak, 1984). Female meadow voles brood and nurse their young less frequently and for shorter periods of time than do female prairie voles. Additionally, whereas meadow voles wean their pups by abandoning the nest and litter 12 to 14 days postpartum, prairie voles nurse their pups for approximately 21 days and continue to remain with them at the initial nest site.

The purpose of the present study was to extend our comparison of maternal investment in meadow and prairie voles by examining the volume and composition of milk produced by the two species. Although substantial differences in daily milk yield or milk composition seem unlikely as meadow and prairie voles differ little in adult female body weight (Dewsbury et al., 1980) and are closely related, meadow vole pups exhibit somewhat depressed growth when reared by foster prairie vole parents (McGuire, 1986). A reduction in parental handling cannot account for the depressed weight of cross-fostered meadow voles for

1 Present address: Allee Laboratory, Univ. Chicago, Chicago, Illinois, 60637, USA. 
those pups reared by prairie vole parents received more parental contact than control pups reared by foster meadow vole parents (McGuire, 1988). Additionally, nest temperatures recorded in a second study one minute after the departure of adults indicated that temperatures within meadow and prairie vole nests are similar $\left(24.5^{\circ} \mathrm{C}\right.$ and $25.1^{\circ} \mathrm{C}$, respectively; Novak, unpublished). The elimination of reduced parental handling and cold stress as factors responsible for the depressed weight of crossfostered meadow voles suggested species differences in early nutrition.

The single published report on the milk of voles and lemmings documents species differences in the composition and volume of milk of reed voles (M. fortis), bank voles (Clethrionomys glareolus), and yellow steppe lemmings (Lagurus luteus; Galantsev et al., 1980). Despite similarities in lactose content, the milk collected from the three species differed with respect to fat and protein. Galantsev et al. (1980) also detected substantial species differences in the volume of milk consumed by young during a single feeding. Although factors such as rate of development of young and maternal pattern of nest visitation might also be involved, the volume differences reported by Galantsev et al. (1980) appear to be largely the result of species differences in adult female body size.

In the present study we collected milk from anesthetized meadow and prairie voles following the injection of oxytocin. We analyzed samples for protein, fat and lactose and obtained an estimate of milk volume from the amount of milk collected during a single milking session. Our method of measuring milk volume differed from that used by Galantsev et al. (1980). We did not assess milk yield from differences in pup body weight before and after feeding for two reasons. First, whereas meadow vole young exhibit well-defined feeding periods, prairie vole pups display tenacious nipple attachment (i.e., pups attach tightly to the teats of their mother for long periods of time), making it difficult to define the beginning and end of a feeding bout. Second, although live-weight increases of pups are frequently used to estimate milk yield in rodents, corrections may be necessary for losses due to defecation and urination (Linzell, 1972).

\section{METHODS}

The meadow voles used in this experiment were third or fourth generation offspring of voles trapped in Massachusetts, and the prairie voles were first generation offspring of voles trapped in Illinois. Voles were housed in aquaria $(26 \times 51 \times 30 \mathrm{~cm})$ that contained a peat-wood shaving substrate and a 10 to $20 \mathrm{~cm}$ thick layer of hay. Sunflower seeds, oats, Purina rabbit chow, cracked corn and water were provided ad lib. All animals were maintained on a $14 \mathrm{~L}: 10 \mathrm{D}$ photoperiod (lights on at $0600 \mathrm{~h}$ ). 
The subjects were five female meadow voles and seven female prairie voles. Each female was housed with an adult male under conditions identical to those described for the main colony and all pairs had successfully reared to weaning at least one previous litter. Once a pregnant female was scheduled for milking, the male was removed on approximately day 18 of the 21-day gestation period to prevent postpartum mating. This separation ensured that females were not pregnant during the collection of milk samples and thereby eliminated complications associated with uterine contractions following the administration of oxytocin. Upon the removal of the male, each aquarium was checked twice daily for the appearance of a litter. The first day that a litter was found was designated day 1 of the lactation period. All meadow and prairie vole subjects had from four to six pups.

Milk samples were collected from meadow and prairie vole females on days 4, 8 and 12 of lactation. Meadow voles do not nurse their young after approximately day 14 postpartum (McGuire \& Novak, 1984), and although prairie vole pups continue to show nipple attachment and appear to be ingesting milk over a 20 day period, we were unable to collect milk from this species on day 16. On each of the 3 days, females were separated from their pups and placed into a holding cage for $1.5 \mathrm{~h}$. At the end of the separation period, females were weighed to determine the appropriate dose of anesthetic, anesthetized by an intramuscular injection of ketamine (1.0 $\mathrm{mg}$ ketamine $/ 10 \mathrm{~g}$ body weight), and given a subcutaneous injection of oxytocin ( 1 unit) to cause milk letdown. Milk collection began $20 \mathrm{~s}$ after the injection of oxytocin. Samples were obtained with an eye dropper attached to a mouth pipette. The eye dropper was placed over a nipple and milk was collected by vigorous suction. Periodically, the collected milk was expelled into a preweighed microcentrifuge tube. A second injection of oxytocin (1 unit) and, if necessary, a second injection of ketamine ( $0.5 \mathrm{mg}$ ketamine/10 $\mathrm{g}$ body weight) were given to each female approximately $15 \mathrm{~min}$ after milking began. Milk collection was terminated when all six nipples of a prairie vole or all eight nipples of a meadow vole were tried in succession and each failed to yield milk after a $10-15 \mathrm{~s}$ period. In order to allow recovery from the anesthesia, we placed females into the holding cage for $30 \mathrm{~min}$ before returning them to their pups. In general, females were separated from their young for a total of $2.5-3.0 \mathrm{~h}$ on each of the 3 days that milk was collected.

At the time of milk collection, we recorded the following data: (1) time to first milk (time from the first oxytocin injection to the appearance of milk), (2) total time per session (time from the first oxytocin injection to the point where all nipples have been tried in succession and none have secreted milk), and (3) weight of milk collected. Samples were stored at $-25^{\circ} \mathrm{C}$ until analysis.

Fat and protein were analyzed sequentially from approximately $50 \mu \mathrm{l}$ aliquots of milk. Each aliquot was placed into a $12 \times 75 \mathrm{~mm}$ glass tube and weighed to the nearest $0.0001 \mathrm{~g}$. Equal amounts $(500 \mu \mathrm{l})$ of $95 \%$ ethanol and petroleum ether were added to each tube and the samples were mixed with a vortex mixer for 15 min. Each sample was then centrifuged $(733 \mathrm{~g})$ for $15 \mathrm{~min}$ and the lipidcontaining liquid portion was poured off into preweighed plastic weigh boats. The weight of the fat in each sample was obtained by reweighing these plastic boats after a $3 \mathrm{~h}$ drying period. The protein-containing residue left in each tube was dried overnight. Following this period, $2 \mathrm{ml}$ of $0.3 \mathrm{~N}$ potassium hydroxide were added to each tube, the samples were mixed periodically, and allowed to dissolve 
for $24 \mathrm{~h}$. A $20 \mu \mathrm{l}$ aliquot of each sample was assayed colorimetrically for protein by the method of Lowry et al. (1951).

For the lactose assay, $20 \mu \mathrm{l}$ samples were diluted (1:19) through the addition of $380 \mu \mathrm{l}$ of water to each tube. Lactose content (mg lactose/100 $\mu \mathrm{l}$ milk) was read on a Yellow Springs Instrument glucose analyzer (model 23) with a buffer and membrane for lactose.

In order to determine the weight of meadow vole and prairie vole milk, we filled $10 \mu 1$ preweighed capillary tubes with milk and weighed these tubes to the nearest $0.0001 \mathrm{~g}$. The values obtained were used to convert the percent weight measures of fat and protein (i.e., $\mathrm{mg}$ fat or protein $/ 100 \mathrm{mg}$ milk) to percent volume measures (i.e., $\mathrm{mg}$ fat or protein $/ 100 \mu \mathrm{l} \mathrm{milk}$ ). The weight of milk collected during a milking session was similarly converted from $\mathrm{mg}$ to $\mu \mathrm{l}$.

Volume data were analyzed using a one-way nested analysis of variance (ANOVA) with species as the between-subject variable; individuals were nested within species and days 4, 8 and 12 served as replicates. One meadow vole and one prairie vole failed to secrete milk during milking sessions on day 4, resulting in two replicates (days 8 and 12) for volume estimates for these two females as compared to three replicates for all other females. Additionally, one of the seven prairie vole subjects was milked only on day 12 to provide milk for the nutritional analysis; the amount of milk obtained from this female was not included in the analysis of milk volume. Sample sizes for the analysis of fat, protein and lactose (Table 1) are frequently smaller than those described for the analysis of milk volume; discrepancies resulted from pooling some prairie vole samples for the composition analysis (described below), the occasional loss of a sample due to equipment failure or the inability to assay for all three milk components in samples of small volume.

\section{RESULTS}

Species differences were not apparent in either the time to first milk or the total time spent obtaining milk from each female. In general,

Table 1

Nutritional composition of meadow vole and prairie vole milk $(\mathrm{mg} / 100 \mu \mathrm{l})$.

\begin{tabular}{lrrrrr}
\hline & Day & $\mathrm{n}^{1}$ & Meadow vole & $\mathrm{n}$ & Prairie vole \\
\hline \multirow{3}{*}{ Fat } & 4 & 3 & $15.1 \pm 1.9$ & 3 & $15.5 \pm 0.3$ \\
& 8 & 5 & $15.1 \pm 2.3$ & 2 & $16.0 \pm 0.9$ \\
Protein & 12 & 5 & $18.3 \pm 3.0$ & 3 & $15.9 \pm 1.9$ \\
& 4 & 3 & $6.7 \pm 0.7$ & 3 & $9.1 \pm 0.4$ \\
Lactose & 8 & 5 & $6.9 \pm 1.1$ & 3 & $6.8 \pm 0.4$ \\
& 12 & 5 & $7.6 \pm 1.0$ & 3 & $7.2 \pm 1.0$ \\
& 4 & 3 & $3.1 \pm 0.4$ & 3 & $2.8 \pm 0.4$ \\
& 8 & 4 & $3.0 \pm 0.4$ & 3 & $2.9 \pm 0.2$ \\
& 12 & 4 & $29 \pm 0.5$ & 2 & $2.7 \pm 0.1$ \\
\hline
\end{tabular}

$1 \mathrm{n}=$ number of samples analyzed; in the case of prairie voles, a sample may contain milk from more than one female. 
milk appeared approximately $4 \mathrm{~min}$ after the first oxytocin injection and milking sessions lasted approximately $32 \mathrm{~min}$. Pronounced species differences, however, were detected for the volume of milk obtained per session: despite significant individual variation within species, the mean volume collected from meadow voles $(\bar{X} \pm \mathrm{SE}=187.6 \pm 33.4 \mu \mathrm{l})$ was greater than that obtained from prairie voles $(57.4 \pm 15.8 \mu \mathrm{l} ; F=11.66$, d.f. $=1,9$, $p<0.01$ ).

Sufficient milk was obtained from meadow voles to permit separate nutritional analyses of samples from individual females at each of the three points of lactation (days 4, 8 and 12). In most instances the milk samples collected from individual prairie voles were too small to analyze separately. It was therefore necessary to pool some of the prairie vole samples from days 4 and 8 prior to analyzing milk composition: all milk collected from prairie voles on either day 4 or day 8 was not pooled and then separated into samples large enough for analysis, but rather the milk collected from 2 or 3 individuals was pooled to create a sample of suitable volume.

The milk of meadow and prairie voles differed little in basic composition (Table 1). When averaged across the three points of lactation, the percent volumes of fat, protein, and lactose in the milk of both species were approximately $16 \%, 7 \%$ and $3 \%$, respectively.

\section{DISCUSSION}

The values reported here for the basic nutritional composition of meadow and prairie vole milk differ somewhat from thiose reported by Galantsev et al. (1980) for the reed vole (Microtus fortis), bank vole (Clethrionomys glareolus) and yellow steppe lemming (Lagurus luteus). Whereas the milk of meadow and prairie voles contained approximately $16 \%$ fat by volume, the proportion of fat in reed vole and yellow steppe lemming milk was $19 \%$ and $14 \%$, respectively. The $7 \%$ protein content of meadow and prairie vole milk was similar to that of the yellow steppe lemming $(8 \%)$ and less than that of the reed vole $(12 \%)$ and bank vole $(11 \%)$. In all five species, however, the lactose content of milk was approximately $3-4 \%$.

Pronounced species differences in estimates of milk volume were noted in both the present study and that by Galantsev et al. (1980). However, entirely different methods of assessing volume were utilized, making direct species comparisons between the studies impossible. Galantsev et al. (1980) measured the amount of milk consumed by litters of reed and bank voles during a single feeding after a $2 \mathrm{~h}$ separation from the 
female; milk yield was estimated by differences in pup body weights before and after feeding. Using this system of live-weight increases of pups, Galantsev et al. (1980) noted, for example, that reed voles produce more milk per pup during a single feeding on days 8-10 of lactation than do bank voles (383 $\mathrm{mg}$ and $188 \mathrm{mg}$, respectively). We measured the volume of meadow and prairie vole milk as the amount of milk collected during a single milking session following a $1.5 \mathrm{~h}$ mother-litter separation; under these experimental conditions, meadow voles produced approximately three times as much milk as did prairie voles. Despite the discovery in both studies of species differences in the volume of milk secreted, the factors responsible for such differences do not appear to be similar; whereas the differences noted by Galantsev et al. (1980) seem to be largely the result of species differences in maternal body size, the volume difference between meadow and prairie voles cannot be explained solely on the basis of adult female body weight.

Daily milk yield varies as a function of maternal body size (Linzell, 1972). The prairie and meadow voles used in this study weighed approximately 35 and $40 \mathrm{~g}$, respectively. Given this $5 \mathrm{~g}$ weight difference, the daily milk yield of prairie voles should be slightly less than that of meadow voles. However, if the dramatic difference in the volume of milk obtained from meadow and prairie voles during a 32 min milking session represents a true species difference in the volume of milk secreted per unit time, then this difference, coupled with established species differences in schedules of nest visitation, suggests that patterns of suckling may differ in prairie and meadow voles. Radiotelemetric data on lactating meadow voles indicate that as early as day 2 postpartum, intervals of $2-4 \mathrm{~h}$ elapse between nest visits by females (Madison, 1978). Although comparable field data are not available for prairie voles, laboratory observations indicate that prairie voles nurse their young more frequently and for longer durations than do meadow voles (McGuire \& Novak, 1984). It is possible, therefore, that while meadow vole females secrete large quantities of milk in a short period of time, prairie vole females produce small quantities of milk over a relatively long time period. Thus, although daily milk yield may be slightly less in prairie voles than in meadow voles as predicted by adult female body weight, substantial differences may occur in the pattern of milk secretion. If meadow and prairie voles do differ in the amount of milk secreted per unit time, the depressed weights noted for cross-fostered meadow voles in an earlier study (McGuire, 1986) may reflect the inability of meadow vole young to adjust to the nursing regimes of their foster prairie vole mothers.

In summary, meadow and prairie voles produce milk of similar com- 
position. The finding that three times as much milk was obtained from meadow voles as from prairie voles during a 32 min session suggests that species differences in patterns of milk secretion may accompany established differences in nursing behavior. Monitoring nursing bouts by females over a $24 \mathrm{~h}$ period and measurement of the volume of milk consumed by pups on a daily basis are necessary to more fully compare mother-pup interactions in these species.

\section{REFERENCES}

1. Dewsbury D. A., Baumbardner D. A., Evans R. L. \& Webster D. G., 1980: Sexual dimorphism for body mass in 13 taxa of muroid rodents under laboratory conditions. J. Mammal., 61: 146-149.

2. Galantsev V. P., Korotetskova L. V. \& Mikhailova G. M., 1980: Some characteristics of the lactation period in the yellow steppe lemming and reed and bank voles. Ekologya, 4: 65-71.

3. Linzell J. L., 1972: Milk yield, energy loss in milk, and mammary gland weight in different species. Dairy Sci. Abstr., 34: $351-360$.

4. Lowry O. H., Rosebrough N., Farr A. L. \& Randall R. J., 1951: Protein measurement with folin phenol reagent. J. Biol. Chem. 193: 265-277.

5. Madison D. M., 1978: Movement indicators of reproductive events among female meadow voles as revealed by radiotelemetry. J. Mammal., 59: 835-843 .

6. McGuire B., 1986: The effects of cross-fostering on the physical and behavioral development of the meadow vole (Microtus pennsylvanicus). $\mathrm{Ph}$. D. dissert., Univ. Massachusetts, Amherst, 1-119.

7. McGuire B., 1988: The effects of cross-fostering on the parental behavior of the meadow vole (Microtus pennsylvanicus). J. Mammal., 69: 332-341.

8. McGuire B. \& Novak M., 1984: A comparison of maternal behavior in the meadow vole (Microtus pennsylvanicus), pine vole (M. pinetorum) and prairie vole (M. ochrogaster). Anim. Behav., 32: 1132-1141.

Received 10 November 1987, Accepted 20 June 1988. 
Betty McGUIRE, Henry HELLER i Melinda NOVAK

\section{SKLAD CHEMICZNY MLEKA U MICROTUS PENNSYLVANICUS I MICROTUS OCHROGASTER}

\section{Streszezenie}

Microtus pennsylvanicus (Ord, 1815) i Microtus ochrogaster (Wagner, 1842) różnia się w częstotliwości i długości karmienia mlodych. Przez porównanie ilości i składu mleka produkowanego przez te gatunki sprawdzono różnice we wzorcach ich wysiłku macierzyńskiego. Próbki mleka byly pobierane w czwartym, ósmym i dwunastym dniu laktacji. Uzyskano szacunki ilości mleka oraz analizowano zawartość bialka, tluszczu i laktozy (Tabela 1).

Skład mleka obu gatunków norników różnil się niewiele. Wyraźne różnice międzygatunkowe wykryto jednak w ilości mleka otrzymywanego za jednym razem. Pomimo dużej zmienności średnia ilość mleka u Microtus pennsylvanicus byla trzykrotnie wyższa niż u Microtus ochrogaster (Tabela 1). Różnice w ilości otrzymywanego mleka nie mogą być tłumaczone wylącznie na podstawie zróżnicowania wielkości samic obu gatunków. Sugerujemy, że różnice gatunkowe w sposobach wydzielania mleka (tzn. ilości mleka wydzielanego na jednostkę czasu) towarzyszą ustalonym różnicom $\mathrm{w}$ behawiorze karmienia. 